\begin{tabular}{|c|c|c|}
\hline \multirow[t]{2}{*}{7} & $\begin{array}{l}\text { International Journal of Current Research in } \\
\text { Biosciences and Plant Biology }\end{array}$ & \\
\hline & Volume $4 \bullet$ Number 8 (August-2017) • ISSN: 2349-8080 (Online) & \\
\hline $\begin{array}{l}\text { EXCELLENT } \\
\text { PUBLISHERS }\end{array}$ & Journal homepage: www.ijcrbp.com & www.jictip coum \\
\hline
\end{tabular}

\title{
Determination of Heavy Metals Content (Cadmium and Lead) in Raw Cow's and Buffalo's Milk
}

\author{
Maria Ahmed El-Ansary*
}

Food Control Department, Faculty of Veterinary Medicine, Alexandria University, Egypt

*Corresponding author.

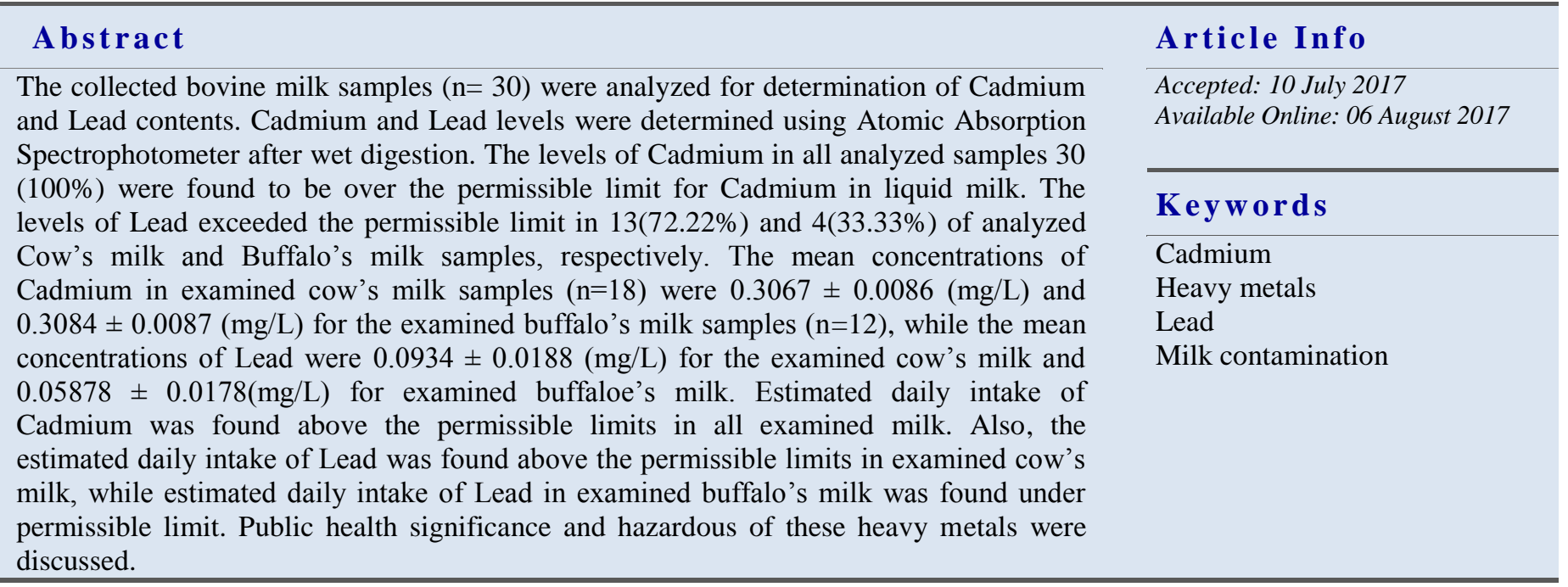

\section{Introduction}

Milk is a primary source of nutrients in diets all around the world (Buldini et al., 2001). Lactating cow's may possibly be exposed to high quantity of toxic elements such as Lead and Cadmium (Jeng et al., 1994). The cattle feed and environment might be the source of heavy metals like Lead and Cadmium in milk and capable of causing serious health problems among the people consuming milk with such contaminants (Monkiewicz et al., 1999). Heavy metals are nonbiodegradable in nature and become accumulated in the food chains via bio-transformation, bio-accumulation and bio-magnifications (Aslam et al., 2011). The presence of heavy metals in milk and dairy products may be attributed to the contamination of the milk during lactation, through feeding stuff, pesticides and water (Carl, 1991).Lead and Cadmium heavy metals are non-essential and have no biological role (Khan et al., 2013). However, at high concentrations, they can cause toxicity to living organisms ( $\mathrm{Li}$ et al, 2005).Accumulation of lead produces damaging effects in the hematopoetical, hematic, renal, gastrointestinal systems (Correia et al., 2000). Due to the growing environmental pollution it is necessary to determine and monitor the levels of heavy metals in milk, because they 
can significantly influence human health (Licata et al., 2004). The aim of this investigation was to determine the levels of toxic heavy metals Cadmium and Lead in raw cow's and buffalo's milk in El-Behera region, Egypt.

\section{Materials and methods}

\section{Milk samples}

A total of 30 raw milk samples (18 cow's milk and 12 buffalo's milk samples) were collected from dairy shops at El-Behera Governorate, Egypt.

Storch's test for detection of heat treated milk samples (Lampert, 1975) was applied for all samples and proofed to be raw milk samples. Atomic absorption spectrophotometer (Licata et al., 2004) was used to determine the lead and cadmium content.

\section{Reagents}

All dissolutions were prepared using analytically pure reagents: Nitric acid and Perchloric acids (Merck, Germany). The detailed procedure followed were from Lajunen (1980) and Haswell (1991)

\section{Digestion procedures}

Prior to digestion, each sample was carefully shaken in its own packing at $40^{\circ} \mathrm{C}$ for 30 minutes on the Rotaterm agitation block.

Wet digestion: One milliliter of homogeneous sample was placed in a $20 \mathrm{~mL}$ tube, mineralized by addition of $3 \mathrm{~mL} \mathrm{HNO} 3-\mathrm{HClO} 4$ (4: 1) mixture and heated to $120^{\circ} \mathrm{C}$ for 65 minutes in a thermostat-controlled digestion block. After cooling, the resulting solution was diluted to $25 \mathrm{~mL}$ with demineralized water. The apparatus has also digital absorbance and concentration read out capable of operating at the following wave length $(\mathrm{nm})$ : 283.3 and 228.9, for Lead and Cadmium, respectively (Agemian et al., 1980) and Perkin-Elmer, 1980).

\section{Data analysis}

The concentrations were expressed as mean \pm SEM and minimum/ maximum values. The data was analyzed using SPSS version 16.

\section{Estimation of daily intake of Cadmium and Lead in examined milk samples}

To evaluate the daily intake, mean concentration of selected heavy metals (Cadmium and Lead) in bovine milk category were multiplied by the milk consumption rate and divided by the body weight $(75 \mathrm{~kg})$ of the adult resident consumer.

\section{Results and discussion}

Cadmium level (Table 1) showed that 18 (100\%) and 12 $(100 \%)$ of examined cow's milk and Buffaloe's milk samples were contaminated with Cadmium, respectively. The mean concentration of Cadmium in raw cow's milk sample was $0.3067 \pm 0.0086 \mathrm{mg} / \mathrm{L}$ with a maximum concentration of $0.3135 \mathrm{mg} / \mathrm{L}$ and minimum concentration of $0.2993 \mathrm{mg} / \mathrm{L}$ (Table 1), while the mean concentration of Cadmium in raw milk samples from buffaloes was $0.3084 \pm 0.0087 \mathrm{mg} / \mathrm{L}$ with a maximum value of $0.3118 \mathrm{mg} / \mathrm{L}$ and a minimum value of 0.3022 $\mathrm{mg} / \mathrm{L}$. Results presented in Table 4 showed that the levels of Cadmium in all analyzed raw cow's milk samples $18(100 \%)$ and Buffaloe's milk samples $12(100 \%)$ were found over the permissible limit of $(0.05$ $\mathrm{mg} / \mathrm{kg}$ ) Cadmium in liquid milk determined by Egyptian standards (2012).

Table 1. Statistical analytical results of concentration of Cadmium $(\mathrm{mg} / \mathrm{L})$ in examined milk samples $(\mathrm{n}=30)$.

\begin{tabular}{lllllll}
\hline \multirow{2}{*}{ Milk sample } & \multirow{2}{*}{ Number } & \multicolumn{2}{l}{ Positive samples } & \multirow{2}{*}{ Minimum } & \multirow{2}{*}{ Maximum } & \multirow{2}{*}{ Mean \pm SEM } \\
\cline { 3 - 6 } & & No. & \% & & & \\
\hline Cow's milk & 18 & 18 & 100 & 0.2993 & 0.3135 & $0.3067 \pm 0.0086$ \\
Buffaloes milk & 12 & 12 & 100 & 0.3022 & 0.3118 & $0.3084 \pm 0.0087$ \\
\hline
\end{tabular}

These results were higher than permissible limits recommended by the Egyptian standards (2012) set it at $0.05 \mathrm{mg} / \mathrm{g}$ for Cadmium in milk. Also, the obtained Cadmium level in this study was higher than the permissible limit of $(0.010 \mathrm{mg} / \mathrm{L})$ for Cadmium in cow milk determined by Commission regulation (EC)
No.1881/2006. Lower results for Cadmium were recorded by Enb et al. (2009), Elsayed et al. (2011), ElBassiony et al. (2016), Gidikova et al. (2016) and Tunegova et al. (2016). Higher results were obtained by Abdulkhalequ et al. (2012) and Gasmalla et al. (2013). Milk and dairy products become contaminated with 
heavy metals either through food stuff and water or through manufacturing and packaging processes (Ayar et al., 2009).

Table 2 showed the level of Lead in examined raw cow milk $(\mathrm{n}=18)$ was ranged from 0.0073 to $0.3407 \mathrm{mg} / \mathrm{L}$ with mean value of $0.0934 \pm 0.0188 \mathrm{mg} / \mathrm{L}$, while the mean value of Lead in examined raw buffaloes milk $(\mathrm{n}=12)$ was $0.05878 \pm 0.01784 \mathrm{mg} / \mathrm{L}$ with a maximum concentration of $0.2358 \mathrm{mg} / \mathrm{L}$ and minimum concentration of $0.0145 \mathrm{mg} / \mathrm{L}$. Results presented in Table 4 showed that there were $4(33.33 \%)$ of examined buffaloe's milk samples and $13(72.22 \%)$ of examined cow's milk samples exceeded the permissible level $(0.10$ $\mathrm{mg} / \mathrm{kg}$ ) for Lead in milk, determined by Egyptian standards (2012).

Table 2. Statistical analytical results of concentration of Lead $(\mathrm{mg} / \mathrm{L})$ in examined milk samples $(\mathrm{n}=30)$.

\begin{tabular}{lllllll}
\hline \multirow{2}{*}{ Milk sample } & \multirow{2}{*}{ Number } & \multicolumn{2}{l}{ Positive samples } & \multirow{2}{*}{ Minimum } & \multirow{2}{*}{ Maximum } & \multirow{2}{*}{ Mean \pm SEM } \\
\cline { 3 - 4 } & & No. & $\mathbf{\%}$ & & & \\
\hline Cow's milk & 18 & 18 & 100 & 0.0073 & 0.3407 & $0.0934 \pm 0.0188$ \\
Buffaloes milk & 12 & 12 & 100 & 0.0145 & 0.2358 & $0.05878 \pm 0.0178$ \\
\hline
\end{tabular}

This value is above the permissible limits of $(0.020 \mathrm{mg} / \mathrm{L})$ determined by Commission regulation (EC) No.1881/2006. According to Codex Alimentarius (2012) the permissible value of Lead in milk and secondary milk products are $0.02 \mathrm{mg} / \mathrm{kg}$. Higher results were recorded by Enb et al., (2009) for Lead in buffaloe's milk and cow's milk in Giza from Egypt. Higher results for lead in raw cow's milk were reported by Gasmalla et al. (2013) and El-Bassiony et al. (2016). Lower results for Cadmium $(1.24 \mu \mathrm{g} / \mathrm{kg})$ and Lead $(3.43 \mu \mathrm{g} / \mathrm{kg})$ in cow's milk were reported by Elatrash and Atoweir (2014) in Libya. Lower results for Lead in cow's milk were recorded by Gidikova et al. (2016) and Muhib et al. (2016). In this study higher levels of heavy metals in cow's and buffalo's milk may be attributed to the high contamination of animal feed and water by such pollutants and could be excreted into milk at various levels. One of the most important sources of Lead contamination in milk is water, especially in more contaminated areas (Codex Alimentarius Commission, 2003).

Table 3. Interspecies comparative mean \pm SEM of Cadmium and Lead (mg/L) in the examined milk samples of cow and buffaloes.

\begin{tabular}{lll}
\hline Residue & Cow's milk & Buffalo's milk \\
\hline Cadmium & $0.3067 \pm 0.0086$ & $0.3084 \pm 0.0087$ \\
Lead & $0.0934 \pm 0.0188$ & $0.05878 \pm 0.0178$ \\
\hline
\end{tabular}

Table 4. Frequency distribution of Cadmium and Lead heavy metals in examined raw cow's and raw Buffalo's milk samples $(\mathrm{n}=30)$.

\begin{tabular}{|c|c|c|c|c|c|c|c|}
\hline \multirow{2}{*}{$\begin{array}{l}\text { Heavy } \\
\text { metal }\end{array}$} & \multirow{2}{*}{$\begin{array}{l}\text { Permissible limit Egyptian } \\
\text { Standards } 2012\end{array}$} & \multicolumn{3}{|c|}{ Samples within permissible limit } & \multicolumn{3}{|c|}{ Samples exceeded permissible limi } \\
\hline & & Milk sample & No. & $\%$ & Milk sample & No. & $\%$ \\
\hline \multirow[t]{2}{*}{ Cadmium } & $0.05 \mathrm{mg} / \mathrm{kg}$ & Buffalo & 0 & 0 & Buffalo & 12 & 100 \\
\hline & & Cow & 0 & 0 & Cow & 18 & 100 \\
\hline \multirow[t]{2}{*}{ Lead } & $0.10 \mathrm{mg} / \mathrm{kg}$ & Buffalo & 8 & 66.66 & Buffalo & 4 & 33.33 \\
\hline & & Cow & 5 & 27.77 & Cow & 13 & 72.22 \\
\hline
\end{tabular}

The presence of heavy metals as Lead and Cadmium even in low concentrations leads to metabolic disorders with extremely serious consequences and causing serious problems as it causes many health problems such as weakness, cancer and also affects the kidneys (Licata et al., 2004).

The heavy metal contents vary widely due to many factors such as differences between species, characteristics of the manufacturing practices and possible contamination coming from the equipment during the process (Caggiano et al., 2005).
The interspecies difference in the residual concentration $(\mathrm{mg} / \mathrm{L})$ of heavy metals (Cadmium and Lead) in the milk of cow and buffalo collected from local markets has been given in Table 3 . The results showed that in the raw milk of cow mean \pm SEM $(\mathrm{mg} / \mathrm{L})$ of Lead $0.0934 \pm 0.0188$ was higher than mean \pm SEM values $(\mathrm{mg} / \mathrm{L})$ of Lead $0.05878 \pm 0.0178$ in raw buffaloes milk, while the mean \pm SEM values $(\mathrm{mg} / \mathrm{L})$ of Cadmium $0.3084 \pm 0.0087$ obtained in the raw milk of buffaloes was higher than the mean \pm SEM values for Cadmium $0.3067 \pm 0.0086$ in raw cow's milk. 
Assuming that a value of 200 ( $\mathrm{ml} /$ day) of raw bovine milk consumption in Egypt. The estimated daily intake of Cadmium and Lead heavy metals were determined and recorded in Table 5, the estimated daily intake of Cadmium in examined raw cow's and Buffaloes milk was $0.8179(\mathrm{mg} /$ day) and 0.8224 (mg/day) respectively, which was higher than the permissible limits 0.046 (mg/day) for Cadmium (JECFA, 2003), while the estimated daily intake of Lead was 0.2491 (mg/day) for cow's milk which exceeded the permissible limits 0.21 (mg/day) for Lead (JECFA, 2003), while the estimated daily intake for buffalo's milk was 0.1567 (mg/day) which is below the permissible limits $0.21(\mathrm{mg} / \mathrm{day})$ for Lead in raw bovine milk.

Table 5. The estimated daily intakes of (Cadmium and Lead) metals from consumption of $200 \mathrm{ml}$ milk of the examined raw milk of cow's and Buffalo's.

\begin{tabular}{lllll}
\hline Heavy metal & Sample & $\begin{array}{l}\text { Estimated daily } \\
\text { intake (mg/day) }\end{array}$ & $\begin{array}{l}\text { Recommended permissible } \\
\text { values (mg/day) }\end{array}$ & Reference \\
\hline Cadmium & Cow's milk & 0.8179 & $0.046(\mathrm{mg} /$ day $)$ & JECFA (2003) \\
& Buffaloe milk & 0.8224 & $0.21(\mathrm{mg} /$ day $)$ & \\
& Cow's milk & 0.2491 & & \\
\hline
\end{tabular}

Thus the daily intake rate of heavy metal hazard quotients and carcinogenic risk might be considered as exponentially increasing trend with the increasing rate of milk production. It can be recommended that proper monitoring of cattle feed quality as well as the techniques of milk processing should be carefully considered for the public health safety in Egypt.

\section{Conclusion}

From the obtained results of this study it could be concluded that all examined raw milk samples contained high concentrations of Cadmium exceeded the permissible limit. Lead levels in a high percent of examined raw cow's milk samples in El-Behera region, are a cause of concern. Risk of heavy metal contamination was higher in raw cow's milk. However, the number of analyzed heavy metals and sample size were limited in this study and further studies are necessary to evaluate of "toxic" heavy metals on a greater number of milk samples from various regions of Egypt.

\section{Conflict of interest statement}

Authors declare that they have no conflict of interest.

\section{References}

Abdulkhaleq, A., Swaileh, K.M., Hussein, R.M., Matani, M., 2012. Levels of metals $(\mathrm{Cd}, \mathrm{Pb}, \mathrm{Cu}$ and $\mathrm{Fe}$ ) in cow's milk, dairy products and hen eggs from the West Bank, Palestine. J. Int. Food Res. 19(3), 1089-1094.

Agemian, H., Sturtevant, D. P., Austen, K. D., 1980.
Simultaneous acid extraction of six trace metals from fish tissues by hot-block digestion and determination by atomic-absorption spectrometry. Analyst. 105, 125-130.

Aslam, B., Jved, I., Hussain, K. F., Ur-Rahman, Z., 2011. Uptake of heavy metal residues from sewerage sludge in the milk of goat and cattle during summer season. J. Pak. Vet. 31(1), 75-77.

Ayar, A., Sert, D., Akin, N., 2009. The trace metal levels in milk and dairy products consumed in middle Anatolia Turkey. Environ. Monit. Assess. 152(1-4), 1-12.

Buldini, P.L., Ricci, R., Sharma, J.L., 2002. Recent applications of sample preparation techniques in food analysis. J. Chromatogr. A. 975(1), 47-70.

Caggiano, R., Sabia, S., D‘Emilio, M., Macchiato, M., Anastasio, A., Ragosta, M., Paino, S., 2005. Metal levels in fodder, milk, dairy products and tissues sampled in ovine farms of southern Italy. Environ. Res. 99, 48-57.

Carl, M., 1991. Heavy Metals and Other Trace Elements. Monographs on Residues and Contaminants in Milk and Milk Products Special Issues 9101, International Dairy Federation (IDF), Belgium. pp.112-119.

Commission Regulation (EC), 2006. No. 1881/2006 of 19 December 2006. Setting maximum levels for certain contaminants in foodstuffs. Official J. Eur. Union, L 364/5-32.

CAC (Codex Alimentarius Commission), 2003. Report of the $35^{\text {th }}$ session of the Codex Committee on Food Additives and Contaminants, Arusha, Tanzania. http://www.codexalimentarius.net/download/report/ 47/A10312ae.pdf.

Codex Alimentarius Commission, 2012. Joint 
FAO/WHO Food standards Programme. Codex Committee on contaminants in Foods. Sixth Sessions, Maastricht. The Netherlands, CF/6 INF/1.

Correia, P.R.M., Oliveira, E., Oliveira, P.V., 2000. Simultaneous determination of $\mathrm{Cd}$ and $\mathrm{Pb}$ in foodstuffs by electrothermal atomic absorption spectrometry. Anal. Chim. Acta. 405, 205-211.

Egyptian Standard (E.O.S.Q.C.), 2012. Egyptian Organization for Standardization and Quality Control.Maximum level of heavy metals contaminant in food in food. ES 2360, Ministry of Industry. Cairo, Egypt.

Elatrash, S., Atoweir, N., 2014. Determination of lead and cadmium in raw cow's milk by Graphite Furnace Atomic Absorption Spectroscopy. Int. J. Chem. Sci. 12(1), 92-100.

El-Bassiony, T. A., Amin, W. F., Ahmed, E. O., 2016. Impact of heavy metals contamination on milk and underground water of the New Valley, Egypt. J. Environ. Sci. Toxicol. Food Technol. 10(8), 23-29.

Elsayed, E. M., Hamed, A.M., Badran, S. M., Mostafa, A. A., 2011. A survey of selected essential and toxic metals in milk in different regions of Egypt using ICP-AES. Int. J. Dairy Sci. 6(2), 158-164.

Enb, A., Abou Donia, M.A., Abd-Rabou, N.S., AbouArab, A.A.K., El Senaity, M.H., 2009. Chemical composition of raw milk and heavy metals behavior during processing of milk products. Global Veterin. 3, 268-275.

Gasmalla, M.A.A., Khadir, K. E., Musa, A., Aboshora, W., Zhao, W., 2013. Evaluation of some physicochemical parameters of three commercial milk products. Pak. J. Food Sci. 23(2), 62-65.

Gidikova, P., Deliradeva, R., Chobanova, S., Prakova, G., Mihailova, G., 2016. Heavy metal contents in homemade milk and cheese from villages with possible risk of environmental pollution. J. Agrobiol. Sci. VI(6), 48-53.

Haswell, S.J., 1991 . Atomic Absorption Spectrometry, Vol. 5, $1^{\text {st }}$ Edn., Elsevier, New York.

Jeng, S. L., Lee, S. J., Lin, S. Y., 1994. Determination of cadmium and lead in raw milk by Graphite Furnace Atomic Absorption Spectrophotometer. J. Dairy Sci. 77(4), 945-949.

JECFA, 2003. Summary and Conclusions of the $61^{\text {st }}$ Meeting of the Joint FAO/WHO Expert Committee on Food Additives (JECFA). Rome, Italy: JECFA /61/SC.

Khan, Z.I., Ahmad, K., Bayat, A., Mukhtar, M.K., Sher, M., 2013. Evaluation of lead concentration in pasture and milk: A possible risk for livestock and public health. Pak. J. Zool. 45(1), 79-84.

Lajunen, L.H.J., 1980. Spectrochemical Analysis by Atomic Absorption and Emission. The Royal Society of Chemistry, Cambridge, U.K.

Lampert, L.M., 1975. Modern Dairy Products. $3^{\text {rd }}$ Edn. Chemical Publishing Co. Inc., New York. 90p.

Li, Y., McCrory, D.F., Powell, J.M., Saam, H., JacksonSmith, D. A., 2005. Survey of selected heavy metal concentrations in Wisconsin dairy feeds. J. Dairy Sci. 88(8), 2911-2922.

Licata, P., Trombetta, D., Cristani, M., Giofrè, F., Martino, D., Calò, M., Naccari, F., 2004. Levels of "toxic" and "essential" metals in samples of bovine milk from various dairy farms in Calabria, Italy. Environ. Int. 30(1), 1-6.

Monkiewicz, J., Forster, J., Geringer, H., Napierala, J., Jopek, Z., Kucharczak, E., 1999. Preventing over accumulation of lead, cadmium, arsenic, copper and zinc in cows kept in polluted environment. Pol. J. Environ. Stud. 8, 117-121.

Muhib, M.d. I., Chowdhury, M. A. Z., Easha, N. J., Rahman, Md. M., Shammi, M., Fardous, Z., Bari, M. L., Uddin, K., Kurasaki, M., Alam, Md. K., 2016. Investigation of heavy metal contents in cow milk samples from area of Dhaka, Bangladesh. Int. J. Food Contamin. 3, 16.

Perkin-Elmer, 1980. Catalogue of Atomic Absorption Spectrophotometry Model 2380, USA.

Tunegova, M., Toman, R., Tancin, V., 2016. Heavy metals environmental contaminants and occurrence in resident types of milk. Slovak. J. Anim. Sci. 49(3), 122-131.

\section{How to cite this article:}

El-Ansary, M. A., 2017. Determination of heavy metals content (Cadmium and Lead) in raw cow's and buffalo's milk. Int. J. Curr. Res. Biosci. Plant Biol. 4(8), 116-120. doi: https://doi.org/10.20546/ijcrbp.2017.408.016 